\title{
Entanglement of State and Indigenous Legal Orders in Canada
}

\author{
KEITH CULVER AND MICHAEL GIUDICE
}

The concept of entangled legality faces an uphill battle for respectability, as powerful human forces weigh against it from the first mention of its terms. We are all familiar with the reductionist impulse in legal theory, which seeks to reduce apparent novelty to ready explanation within extant concepts and categories. Assertions of legal entanglement, on this view, are mistaken ascriptions of something else - perhaps conflicts between sovereign states, or unsettled internal constitutional matters as federal and state authorities contest the boundaries between them. And even if the ontological credibility of entangled legality might be established, a familiar meliorist impulse may emerge, presuming that what is entangled is better off disentangled, leaving entangled legality a concept less seen in practice than spoken of when practice goes awry. Entanglement, after all, is rarely a good thing. We generally seek to keep marine life from becoming entangled in fishing gear, we often try to help friends out of romantic entanglements and we certainly do not want our political representatives to be entangled in scandal. Here we push back against these impulses, arguing first that entangled legality is not reducible to some familiar other concept or category, and second, that entangled legality can be both durable and a force for political good, even while its durable presence raises challenges to state-centred approaches to legal theory. Contrary to intuition and impulse, then, we argue that entangled legality is here to stay in both legal practice and in legal theory, and that both may be better off embracing entanglement.

The context of our argument is the rapidly evolving relations between state and Indigenous ${ }^{1}$ legal orders in Canada. As we argue at length, the emergence of entanglement between these legal orders offers a clear instance of entanglement unlikely to be better explained by reduction

${ }^{1}$ A note on terminology: for the purposes of this chapter, we use as interchangeable 'Indigenous peoples', 'Aboriginal peoples' and 'First Nations'. 
to existing relations and explanations, and moreover, this entanglement presents what may over time become the replacement of Canada's foundational unitary constitution by an equally durable pluriform foundation.

A brief foreshadowing of the context of our argument together with an explanation of its structure will serve as a helpful beginning. Canada was created in 1867 with the Constitution Act, 1867 (also known as the British North America Act, 1867, an act of the United Kingdom Parliament). Sections 91 and 92 of the Constitution Act, 1867 divide the powers and authority of the Canadian state, without remainder, between the federal and provincial governments. No constitutional power or authority is allocated to Indigenous peoples. Indigenous rights and claims have nonetheless been recognized in diverse ways since 1867. The Indian Act, 1876, a constitutional amendment in 1982 and several Supreme Court of Canada decisions have acknowledged the existence of Indigenous legal orders, albeit always through the particular lens of the Canadian legal institution undertaking an act of recognition - viewing claims of Indigenous law from the perspective and authority of the Canadian legal system and subject to the limitations set by Crown sovereignty and associated doctrines. Until very recently, this interaction was readily explained by what we have called elsewhere a state-centred approach to legal theory, taking the legal system of the sovereign state as the central instance and object of legal theory as a consequence of the sovereign state's centrality to legal order in the post-Westphalian era. ${ }^{2}$

The bulk of our argument presents evidence for the claim that practically and theoretically significant changes are occurring in the way Canadian legal institutions are engaging with Indigenous peoples' legal claims rooted in the assertion of the existence of Indigenous legal orders existing without recourse to Canadian recognition as a condition of their existence. We demonstrate a gradual yet unmistakably foundational change as institutions of the Canadian legal system embrace a different approach to recognizing Indigenous peoples' rights, claims and legal orders, through various letters of understanding, framework agreements and protocols. This new approach suggests a reconception of the basic terms of what this volume refers to as entangled legalities, from a supremacy-claiming systematicity view to one

${ }^{2}$ See K. Culver and M. Giudice, Legality's Borders: An Essay in General Jurisprudence (Oxford University Press, 2010); and K. Culver and M. Giudice, The Unsteady State: General Jurisprudence for Dynamic Social Phenomena (Cambridge University Press, 2017). 
of 'government-to-government' partnership between state (federal and provincial) governments and Indigenous governments.

We proceed as follows. In Section 14.1, we show how claims to supreme authority made by Canada's legal institutions have exemplified the descriptive-explanatory picture of law offered by state-centred analytical legal theory, while noting along the way the beginnings of recognition of the limitations or inaptness of such claims in the context of Canada's changing relation with Indigenous peoples and their legal orders. In Section 14.2, we provide historical and recent Canadian evidence for the contingency of the relation between systemic claims of supremacy and the presence of durable legal order. Legal order, we argue, can and does exist in conditions of entanglement where there are no overarching legal systems claiming and enjoying some degree of supreme authority. In Section 14.3, we suggest an alternative to the system-centred view and the insistence on the necessity of a supremacy-claiming authority to the existence of durable legal order. That alternative was introduced in previous work, and is developed further here in the context of stateIndigenous entangled legality in Canada.

\subsection{Supremacy Claims and Legal System}

Generations of students of law and legal theory are familiar with the simple yet powerful characterization of the nature of law developed by H. L. A. Hart and those following in the analytical legal theory tradition to which he gave fresh life. According to Hart's famous formulation in The Concept of Law, for a legal system to exist there must be a union of primary rules of obligation, which direct norm-subjects in what they must and must not do, and secondary rules, primarily addressed to and operated by legal officials, authorizing the creation, application and enforcement of primary rules as well as setting in general terms how the primary rules are to be identified or recognized in the first place. ${ }^{3}$ Many institutions have such a union of primary and secondary rules, such as hospitals, schools and sports associations, so what makes legal systems - especially of the sovereign state kind - distinctive is that, unlike other institutions, a legal system makes a general claim to supremacy over all other types of normative systems. In the 'Postscript', first included in the second edition of The Concept of Law, Hart writes: 'the

${ }^{3}$ H. L. A. Hart, The Concept of Law, 3rd ed. (Oxford University Press, 2012). 
distinctive features of law are the provision it makes by secondary rules for the identification, change, and enforcement of its standards and the general claim it makes to priority over other standards. ${ }^{4}$ While Hart left the notion of supremacy or 'priority' with little further development of its content, the idea became central to Joseph Raz's largely complementary explanation of the concept of legal system. As Raz explains, in addition to comprehensiveness and openness, a general claim to supremacy is one of the unique and distinguishing characteristics of legal systems:

The condition means that every legal system claims authority to regulate the setting up and application of other institutionalized systems by its subject-community. In other words, it claims authority to prohibit, permit, or impose conditions on the institution and operation of all the normative organizations to which members of its subject-community belong. ${ }^{5}$

Raz offers this observation in the context of discussion about the necessary features 'of all the intuitively clear instances of municipal legal systems.' ${ }^{6}$ Raz's claim is carefully delimited, announcing a focus on obvious central instances of state systems of law, leaving unexamined what might be regarded as borderline cases, and forms of legal order beyond the state, as may be found in international law. Yet even Raz's delimited claim is subject to doubt, as critics argue that it may not be necessary to the nature of law that it claims supremacy, whether in state systems or other legal orders. ${ }^{7}$ Here we leave this debate to one side, while observing that our argument regarding entangled legality in Canada supports the view that the relation between law and claims to supremacy is a contingent relation. So while our primary goals remain the demonstration of the existence of entangled legality and argument that entangled legality may be a good thing, our argument is of additional interest to the extent that it has implications for the project of general jurisprudence as an attempt to develop an explanation of law capable of scoping over all instances, without limitation to the post-Westphalian state which has dominated so much discussion at least since the initial 1961 publication of The Concept of Law.

${ }^{4}$ Ibid., p. 249 (emphasis added).

${ }^{5}$ J. Raz, The Authority of Law, 2nd ed. (Oxford University Press, 2009), p. 118.

${ }^{6}$ Ibid., p. 104.

7 See, e.g., A. Marmor, Positive Law and Objective Values (Oxford University Press, 2001), p. 40; and B. Tamanaha, A General Jurisprudence of Law and Society (Oxford University Press, 2001), p. 140. 
The utility and limitations of the supremacy claim are usefully explored in application of the claim to explain the Canadian context in both historic perspective, and as new evidence shows Canadian adoption of something other than a supremacy claim in the self-conception of the Canadian legal system and the Canadian polity. Claims of supremacy have certainly been prominent, but now seem to be withdrawn in certain instances with regards to some Indigenous peoples, creating an explanatory demand unmet by the supremacy claim. Let us set out an outline of the historical presence of the supremacy claim, in preparation for demonstration of its recent retreat.

The supremacy claim has (at least) three dimensions, divided as follows.

Supremacy of norms. Like other sovereign states, at the foundation of the Canadian legal system is a unitary constitution, first the Constitution Act, 1867, now the Constitution Act, 1982. And like other state constitutions, the Constitution Act, 1982 contains a common supremacy clause. Section 52(1) reads: 'The Constitution of Canada is the supreme law of Canada, and any law that is inconsistent with the provisions of the Constitution is, to the extent of the inconsistency, of no force or effect.' ${ }^{8}$ There is of course more than just constitutional law in Canada: there is federal law and regulation, provincial law and regulation, and judicial precedents. Yet these all occupy a particular place in the hierarchy of norms in Canada, with constitutional law serving as the top-down source of validity or authorization for all other types of law. The supremacy claim of the Canadian constitution, and its associated hierarchy of sources of law, is readily observable. John Borrows, for example, recounts the first time he encountered the idea of hierarchy as a law student in Canada:

I remember my property law professor telling me that all laws had to be consistent with the Constitution Acts to be valid. Then we were told that below the Constitution were parliamentary or legislative enactments, which were greater in authority than common law pronouncements made by judges. Underneath these sources came law's subsidiary origins, such as parliamentary privilege, the royal prerogative, particularly persuasive published commentaries, followed finally by customs and conventions. This pattern for organizing the sources of Canadian law is evident in many of today's legal textbooks. I could not help but notice that custom

8 The Constitution Act, 1982, section 52, https://laws-lois.justice.gc.ca/eng/const/page-16 .html\#docCont. 
was at the bottom of Canada's legal structure, and that custom was the kind of law Indigenous peoples were presumed to have, if they were regarded as having any law at all. ${ }^{9}$

One might suppose that including Indigenous rights within the Constitution of Canada would raise the level of protection of Indigenous law and so place it higher up in the hierarchy of Canada's legal system. Such inclusion happened in 1982 with the creation of the Constitution Act, 1982. Section 35(1) reads: 'The existing aboriginal and treaty rights of the aboriginal peoples of Canada are hereby recognized and affirmed. ${ }^{, 0}$ Yet it must be remembered that such recognition and affirmation are granted by the Constitution of Canada, and subject to amendment according to the amendment formula laid out in the Constitution. While there is a constitutional obligation to consult with Indigenous peoples in Canada regarding any amendment to sections 25 or 35 of the Constitution Act, 1982 or other parts of the Constitution which refer to Indigenous rights, any subsequent amendment only requires approval by a combination of federal and provincial governments. The approval of Indigenous governments is not required. ${ }^{11}$ This constitutional recognition of 'existing aboriginal and treaty rights' is evidently more substantial than mere recognition of the existence of residual customary Indigenous law, but that recognition remains an elaboration of the detail of the Canadian legal system's supremacy claim, subsuming Indigenous rights, interests and laws within the Canadian constitutional order.

Supremacy of institutions. Canadian supremacy claims relative to Indigenous peoples' law and legal order are also visible in the status and role of central institutions. Federal and provincial governments are granted exhaustive lawmaking authority under the Constitution, and federal and provincial courts are presumed to have exhaustive authority to resolve disputes. Indeed, as the highest court in Canada, the Supreme Court of Canada, through its judgements and opinions offers final, authoritative decisions on matters regarding Indigenous rights in Canada. As such, the Supreme Court of Canada naturally derives its authority and validity for its decisions through its place in the hierarchy of norms and institutions of the supreme, comprehensive, independent legal system in Canada. Viewing Indigenous rights through the lens of

\footnotetext{
9 J. Borrows, Canada's Indigenous Constitution (University of Toronto Press, 2010), p. 13.

10 See The Constitution Act, 1982.

11 Ibid.
} 
the Supreme Court of Canada is of course to view Indigenous rights through a lens which presumes the underlying supremacy of that court and the legal order it implements, and moreover, lacks the institutional means to interrogate or vary this presumption. The force of this presumption is usefully emphasized by Patricia Monture-Angus:

There is an insurmountable problem in taking Aboriginal claims to territory before the courts. Courts owe their creation to the fact of Canadian sovereignty. They cannot question that sovereignty because, to find it wanting would in fact dis-establish their own legitimacy. Without legitimate claim and control over territory, the international definition of sovereignty collapses. ${ }^{12}$

Aaron Mills offers a similar observation in the context of discussion of the nature of treaty relationships in Canada:

The structural relation of settler supremacy that characterizes CanadaIndigenous relationships means that even if somehow the Supreme Court of Canada could get the doctrine right, inequality between Indigenous and settler peoples would persist. Yet the overarching theme of this book is treaty remedies. It will be clear by now that I think that's the wrong frame for thinking about changing treaty relationships today because it assumes too much, namely that the courts have a leading role to play in reorganizing treaty relationships. The courts are an institution internal to Canada's constitutional order and, as creations by and under its authority, are by definition incapable of taking up the very issue at stake in treaty: the coordination of distinct constitutional orders. ${ }^{13}$

Similarly, Mark Walters identifies several instances where Indigenous peoples have denied - to little practical effect - the authority and sovereignty of the Canadian state and its institutions. That denial amounts to what Walters aptly calls an 'existential threat' to Canadian sovereignty, swiftly rejected by Canadian courts. Here is an example:

When it was argued that an interlocutory injunction against protesters from the Lilwat people was invalid 'because the Lilwat People constitute a sovereign nation to which the laws of Canada do not apply and over which the Courts have no jurisdiction,' the response from provincial

12 P. Monture-Angus, Journeying Forward: Dreaming First Nations' Independence (Fernwood Publishing, 1999), p. 65 (internal notes omitted).

13 A. Mills, 'What Is a Treaty? On Contract and Mutual Aid', in J. Borrows and M. Coyle (eds), The Right Relationship: Reimagining the Implementation of Historical Treaties (University of Toronto Press, 2017), pp. 223-4 (internal notes omitted, original emphasis). 
lawyers, that this 'Indian sovereignty argument challenges the basic constitutional framework of Canada,' was probably fair, in the sense that the Aboriginal sovereignty claim was made against, not under or pursuant to, the Constitution of Canada ... Often Indigenous claimants ... invoke international law as well as the laws of their Indigenous nation against the validity of the Canadian state. In general, judges respond to existential threat cases by quickly denying the claims, often by citing the sovereigntywithout-a-doubt passage from Sparrow and/or the act of state doctrine. ${ }^{14}$

While the Supreme Court of Canada and other Canadian courts have on occasion questioned their jurisdiction to hear certain disputes, and sometimes refuse to offer judgements or opinions on issues they find not (or not yet) justiciable, there is entirely unsurprisingly little historical indication that courts conceived of themselves as institutionally able to question their general legitimacy as institutions of the sovereign Canadian state. ${ }^{15}$ Yet as sometimes happens in social affairs, a sea change in attitudes and eventually practice has occurred in recent years, for various reasons beyond easy traceability, but with significant effects. ${ }^{16}$ For example, in a 2014 decision then Chief Justice McLachlin of the Supreme Court wrote this about the test for establishing Aboriginal title to land:

what is required is a culturally sensitive approach to sufficiency of occupation based on the dual perspectives of the Aboriginal group in question - its laws, practices, size, technological ability and the character of the land claimed - and the common law notion of possession as a basis for title. It is not possible to list every indicia of occupation that might apply in a particular case. The common law test for possession - which requires an intention to occupy or hold land for the purposes of the occupant must be considered alongside the perspective of the Aboriginal group which, depending on its size and manner of living, might conceive of possession of land in a somewhat different manner than did the common law. ${ }^{17}$

${ }^{14}$ M. D. Walters, “Looking for a Knot in the Bulrush": Reflections on Law, Sovereignty, and Aboriginal Rights', in P. Macklem and D. Sanderson (eds), From Recognition to Reconciliation: Essays on the Constitutional Entrenchment of Aboriginal and Treaty Rights (University of Toronto Press, 2016), pp. 54-5 (author's notes omitted).

15 Even more unlikely would be to find acknowledgment by the Supreme Court of Canada (or any other Canadian court) that its authority to decide disputes regarding the status and nature of Indigenous rights depends on delegation or recognition by First Nations.

${ }^{16}$ Among these causes it is worth identifying the work of the Truth and Reconciliation Commission emerging from an inquiry into residential schools in Canada. See generally: www.trc.ca/about-us/our-mandate.html.

17 Tsilhqot'in Nation v. British Columbia [2014] 2 S.C.R. 256. 
Consideration of the 'dual perspectives' of Aboriginal groups and the common law when establishing title is a marked change from the Indian Act and earlier Aboriginal title decisions, but it still presumes that authority to make binding decisions regarding Aboriginal title rests with state courts and institutions, not Aboriginal ones. It is nonetheless clear that the demand for judgement incorporating 'dual perspectives' is the foundation of not just recognition of de facto entanglement, but choice of entanglement in the growth of the body of constitutional norms.

Supremacy of force. A further characteristic claim of legal systems of sovereign states, found hand in hand with claims of supremacy of norms and supremacy of institutions, is the claim to a monopoly on the lawful use of force. The Supreme Court of Canada has expressed this dimension of the Canadian supremacy claim in the course of identifying limits to Aboriginal rights in its 2001 decision Mitchell v. M.N.R.:

Canadian sovereign authority has, as one of its inherent characteristics, a monopoly on the lawful use of military force within its territory. I do not accept that the Mohawks could acquire under s. 35(1) a legal right to deploy a military force in what is now Canada, as and when they choose to do so, even if the warrior tradition was to be considered a defining feature of pre-contact Mohawk society. Section 35(1) should not be interpreted to throw on the Crown the burden of demonstrating subsequent extinguishment by 'clear and plain' measures [...] of a 'right' to organize a private army, or a requirement to justify such a limitation after 1982 under the Sparrow standard. This example, remote as it is from the particular claim advanced in this case, usefully illustrates the principled limitation flowing from sovereign incompatibility in the s. 35(1) analysis. $^{18}$

At the risk of belabouring the point, claims of supremacy of norms, institutions and the use of force in Canada all support the central observation in this section, that Indigenous rights, norms and institutions, to the extent to which they have legal status and force in Canada, have depended on the authorization and permission of the Canadian legal system. The approach to characterization of law and legal system developed by Hart, Raz and following analytical legal theorists is readily capable of explaining the Canadian situation and the respects in which it resembles and varies from other legal systems. That approach is equally capable of reminding us that the patterns of recognition just surveyed may or may not be indicative of a durable legal system combining claims

${ }^{18}$ Mitchell v. M.N.R. [2001] 1. S.C.R. 911, para. 153 (original emphasis). 
to authority in fact generally accepted and practised by the society with which the legal system exists in an intimate relationship. In a relatively durable system such as that found in Canada, supremacy claims are generally accepted, as when provincial and federal governments accept the supremacy of constitutional law over their legislative acts (e.g. where courts strike down some legislative provision citing violation of a Canadian Charter right or provision), or when the police cede authority to the military over the use of force in times of emergency or martial rule. In other instances, claims to supremacy can be rejected in ways that are not readily explained as mere rule-breaking, or as attempts at revolution resulting in the dissolution of the state. Rejection of claims of supremacy of the Canadian legal system by Indigenous peoples are easily found, in contexts of entanglement where durable models for social life are sought beyond the discourse available in a supremacy-presuming state and peoples subject to its supremacy claim. For example, in This Is Not a Peace Pipe, Dale Turner begins with the following observations about the legal status of Aboriginal rights in Canada:

Aboriginal rights, as constitutional rights, are still developing in law; that said, one important principle is now embedded in Canadian law and politics: the meaning and content of Aboriginal rights is expressed in the legal and political discourses of the Canadian state, and therefore Aboriginal rights exist or have legitimacy only within the Canadian state [...] But many Aboriginal peoples do not understand their rights in terms that are amenable to the state's legal and political discourses. This is because many Aboriginal peoples do not perceive the political relationship as one of subservience; that is, they do not view their rights as somehow legitimated by the Canadian state. Rather, many Aboriginal peoples understand the political relationship as one of 'nation to nation. ${ }^{19}$

In some instances, First Nations not only claim independence as sovereign nations alongside Canada, but assert a kind of reversal of the hierarchy and stream of supremacy claims. Some First Nations assert authority to validate the inclusion of settler peoples and institutions into the family of legal orders present in North America. For example, Turner notes this particular feature of an Iroquoian treaty known as 'the Guswentha' or 'Two Row Wampum', an agreement which symbolizes

19 D. Turner, This Is Not a Peace Pipe: Towards a Critical Indigenous Philosophy (University of Toronto Press, 2006), pp. 3-4 (original emphasis). 
'peace, friendship, and respect ${ }^{20}$ and serves to constitute the relationship and standing between Indigenous peoples and settlers:

One reason why the Two Row Wampum is useful for a kind of 'panindigenous' political thinking is that it demonstrates that European nations became nations because of the forms of political recognition the Iroquois bestowed on them. The kind of nationhood that remains embedded in Iroquois has retained its normative force throughout the historical relationship. This supports $\mathrm{McNeil}$ and Borrows's thesis that the Canadian legal system has gained its legitimacy by virtue of indigenous law. $^{21}$

This reversed supremacy claim is of interest as a matter of both the history of the relations between Indigenous peoples and the Canadian state, and for reasons internal to the Canadian state and its selfunderstanding. Borrows has done perhaps more than anyone else to show that the creation of the Canadian state and its legal system has in its roots a nation-to-nation treaty, recognized, for example, by the Royal Proclamation of $1763 .^{22}$ As Borrows argues, the Royal Proclamation of 1763 presumes, and was understood by Indigenous peoples at the time as recognizing, equal standing between Indigenous peoples and settler peoples, including the British Crown itself. On such a view there was no domination of one nation or government over another, but acknowledgement that the validity of agreements regarding the use and title of land, respective self-government and all other aspects of interaction required mutual recognition. Borrows sets this understanding of the relationship between Indigenous peoples and settler peoples in Canada in stark contrast to the view of a unilateral assertion of Crown sovereignty, which prevailed around the time of Confederation in 1867 and continues in many ways until the present day, marking a kind of deliberate Canadian forgetfulness made possible by the prevailing imbalance in political power between the thoroughly established settlers and the

${ }^{20}$ On the origins of the Guswentha or Two Row Wampum, see Turner, This Is Not a Peace Pipe, p. 48, quoting Grand Chief Michael Mitchell of Akwesane.

${ }^{21}$ Ibid., pp. 54-5 (original emphasis).

22 See J. Borrows, 'Constitutional Law from a First Nation Perspective: Self-government and the Royal Proclamation' (1994) 28 University of British Columbia Law Review 1-47; J. Borrows, 'Canada's Colonial Constitution', in J. Borrows and M. Coyle (eds), The Right Relationship: Reimagining the Implementation of Historical Treaties (University of Toronto Press, 2017), pp. 17-38; J. Borrows, Recovering Canada: The Resurgence of Indigenous Law (University of Toronto Press, 2002); and J. Borrows, Freedom and Indigenous Constitutionalism (University of Toronto Press, 2016). 
substantially displaced Indigenous peoples. There is nonetheless room in the content of the Canadian legal system's self-conception for a return to a collaborative, entangled stance with respect to Indigenous legal orders, warranting further attention to past and present conditions of engagement between Canadian and Indigenous legal orders.

Borrows' work is again instructive. In light of the Supreme Court's acknowledgement of the need for a 'dual perspective', we can ask the question of what, from a First Nations perspective, gives treaties between Indigenous peoples and settler peoples their validity, which sets terms for engagement and perhaps entanglement. Borrows notes that for many Indigenous peoples, there is an important idea of sacred law: 'Laws can be regarded as sacred if they stem from the Creator, creation stories or revered ancient teachings that have withstood the test of time. When laws exist within these categories they are often given the highest respect. ${ }^{23}$ Sacred laws, then, as supreme laws or laws deserving the highest respect, can serve as the source of validity for treaties. Borrows explains how this view can be found regarding treaties signed in parts of Western Canada:

I encountered this view when working with Elders in Saskatchewan. They spoke of their treaties as being sacred because they brought Canada into existence within their territories [...] In listening to the Elders speak about the meanings of these legally binding promises, it was clear that they regarded the treaty as flowing from a sacred source. They did not rely on the written text of the treaty to arrive at this conclusion. Because First Nations followed their own legal traditions in creating treaties, their interpretation was that treaties were made with the Creator as well as the Crown. ${ }^{24}$

As Borrows explains, however, the Creator and Crown are not on equal footing in this respect. The Crown, much like Indigenous peoples, is subject to the laws of the Creator, who is supreme. Borrows quotes one particular Elder:

It was the will of the Creator that the White man would come to live with us, among us, to share our lives together with him, and also both of us collectively to benefit from bounty of Mother Earth for all time to come [...] Just like the treaty, that's what it is, one law was given, Indian and white, we both gave something special, something to keep, something to reverence, just like the treaty, both Indian and white beneficiaries, we were

\footnotetext{
${ }^{23}$ Borrows, Canada's Indigenous Constitution, p. 24.

24 Ibid., pp. 25-6.
} 
given a gift from the Creator. The Creator owns us, he is still the boss, nothing is hidden. ${ }^{25}$

As we saw earlier, there is a long history of assertions of the supremacy of the Canadian legal system over First Nations, largely matched by First Nations' acquiescence or practical inability to contest those claims even when the claims arguably amounted to Canadian self-misunderstanding omitting recognition of the force of prior treaty agreements. There is nonetheless an additional history of competing assertions of independence on the part of First Nations, although these assertions most often do not also claim to serve as authority over settler laws. In the passage just quoted, however, we do have an example where sacred Indigenous law is the source of validity for other Indigenous laws and treaties, and additionally claims to serve as the source of validity for the presence of settler peoples and their laws.

\subsection{The Contingent Relation between Supremacy Claims and Law}

We now arrive at a crucial question: are assertions of the existence of legal system, and in particular assertions of supremacy of the kind visible in the Canadian legal system, necessary or inevitable in understanding and constructing the relations between state governments and Indigenous governments in Canada? Historical evidence and recent agreements suggest the answer is 'no'. Historically, assertions of legal systems and claims of supremacy were not always the way that settler peoples and institutions related to Indigenous peoples in what is now Canada, and very recently there seem to be instances of a return - or at least steps towards a return - to older ways of conceiving such relations. Looking first at pre-Confederation times, we can find evidence of a preference, on the part of many Indigenous peoples, for the terms of the Royal Proclamation of 1763, issued by the British Crown, over the terms and understanding of the British North America Act of 1867 (also known as the Constitution Act, 1867) which created modern-day Canada. Borrows again offers a helpful account. He argues that while the Royal Proclamation has appeared to Canadian courts as an effective unilateral assertion of Crown sovereignty, it was understood by First Nations at the time to be an important nation-to-nation treaty of peace

${ }^{25}$ Ibid., p. 26. 
and friendship, which would honour First Nations' ownership of land and self-government. ${ }^{26}$ The Royal Proclamation, in this sense, was understood by First Nations to be a kind of sovereignty-protecting international treaty. This understanding and relationship was threatened, as many First Nations believed, by the Constitution Act, 1867, as well as the subsequent patriation of the constitution to include a domestic amending formula:

For most Canadians, the lack of a domestic amending formula led them to seek constitutional reform in 1927, 1931, 1935-6, 1950, 1960-1, and 1964. Indigenous peoples were not part of these efforts, because they were not invited, and may not have even been interested had such an invitation been extended. As noted, many Indigenous people regarded the Queen as their ally and the Canadian state as their oppressor and thus saw domestication as a great political and legal evil. The substitution of the Canadian state for the British Crown would not have been regarded as a positive development. This fact has led many Indigenous peoples through the years to declare that they possessed or desired a stronger constitutional relationship with Britain, as opposed to a diminished one. When the British (rather than the Canadian) Crown was regarded as their partner, a nation-to-nation relationship with the British Crown made greater political sense. ${ }^{27}$

For many Indigenous peoples the idea of a nation-to-nation treaty or partnership is best exemplified by the Guswentha or Two Row Wampum mentioned in Section 14.1, a form of treaty which originated in agreements between Indigenous peoples (such as the Iroquois or Haudenosaunee) and European settlers. Turner quotes this well-known explanation of the Two Row Wampum:

When the Haudenosaunee first came into contact with the European nations, treaties of peace and friendship were made. Each was symbolized

26

Borrows, 'Constitutional Law from a First Nation Perspective'. Many First Nations continue to make reference to the Royal Proclamation of 1763 in their claims. For example, the Kingsclear First Nation cites the Royal Proclamation as law protecting their rights to land which was violated on several occasions throughout their history in what is now New Brunswick. See www.kingsclear.ca/about/history/.

27

Borrows, Freedom and Indigenous Constitutionalism, p. 114. See also Borrows, Canada's Indigenous Constitution, pp. 26-7. For comparison, in New Zealand, renewed respect for the Treaty of Waitangi of 1840 began and has continued to grow since 1986, when the state introduced the first of several legislative acts recognizing the Treaty as a source of law in New Zealand. For an account of some of the similarities and differences in Indigenous-settler relations between Canada and New Zealand, see J. Ruru, 'Constitutional Indigenous Jurisprudence in Aotearoa, New Zealand', in P. Macklem and D. Sanderson (eds), From Recognition to Reconciliation, pp. 415-48. 
by the Gus-Wen-The or Two Row Wampum. There is a bed of white wampum which symbolizes the purity of the agreement. There are two rows of purple, and those rows have the spirit of your ancestors and mine. There are three beads of wampum separating the two rows and they symbolize peace, friendship, and respect.

These two rows symbolize two paths or vessels, traveling down the same rivers together. One, a birch bark canoe, will be for the Indian people, their laws, their customs, their ways. The other, a ship, will be for the white people and their laws, their customs and their ways. We shall each travel the river together, side by side, but in our own boat. Neither of us will try to steer the other's vessel.

The principles of the Two Row Wampum became the basis for all treaties and agreements that were made with the Europeans and later the Americans. $^{28}$

Despite these First Nations perspectives, the idea of a nation-to-nation treaty or partnership did not survive in settler understanding and was simply given no recognition at the time of Confederation in 1867 and subsequent practice. As the above account showed, the Canadian state opted for the extinguishment and then subsumption of Indigenous legal orders. Recently, however, the idea of a nation-to-nation partnership has resurfaced. In various framework agreements, letters of understanding and reconciliation protocols signed by First Nations and provincial and federal governments, relations are being expressed and understood not in a hierarchical or delegated fashion, but rather as relations of 'government-to-government' or 'true partnership'. ${ }^{29}$ Many of these agreements

28 Turner, This Is Not a Peace Pipe, p. 48 (internal notes omitted). See also Mitchell v. M.N.R., paras 127-30. Also valuable on the importance of such an understanding of state-settler relations is J. Tully, Strange Multiplicity: Constitutionalism in an Age of Diversity (Cambridge University Press, 1995). Tully does not examine the relations through the lens of the concept of legal system, but his account of the difference between ancient constitutionalism, modern constitutionalism and contemporary constitutionalism offers a nice parallel.

${ }^{29}$ See, for example, the Letter of Understanding between the Tsilhqot'in Nation and the Government of British Columbia (2014), www.tsilhqotin.ca/Portals/0/PDFs/LOU_ Tsilhqotin_BC.pdf; the Letter of Understanding between the Tsilhqot'in Nation and the Government of Canada (2017), www.tsilhqotin.ca/Portals/0/PDFs/Press\%20Releases/ 2017_01_27_Tsilhqotin_Canada_LOU.pdf; Kunst'aa guu - Kunst'aayah Reconciliation Protocol, signed between the government of British Columbia and the Haida Nation (2009), www.haidanation.ca/wp-content/uploads/2017/03/Kunstaa-guu_Kunstaayah_ Agreement.pdf; and the Shíshálh Government-to-Government Agreement (2018), www2.gov.bc.ca/assets/gov/environment/natural-resource-stewardship/consulting-withfirst-nations/agreements/shishalh_g2g_2016-06-21_final_-_public.pdf. 
are quite recent, so have yet to be seen in full operation, but an early framework agreement and subsequent legislation and practice provide a good illustration of the way in which state and First Nations relations are evolving. The Framework Agreement on First Nation Land Management was created in 1996 and signed by the government of Canada and thirteen First Nations, and is expressly characterized as a 'governmentto-government' agreement. ${ }^{30}$ The central purpose of the Framework Agreement is to allow 'First Nations to opt out of the land management sections of the Indian Act and take over responsibility for the management and control of their reserve lands and resources'. ${ }^{31}$ As its name suggests, the Framework Agreement has since served as a framework and source of law for both the government of Canada as well as First Nations:

Canada enacted the First Nations Land Management Act (FNLMA), as part of its obligation to ratify the Framework Agreement. It was given royal assent on June 17, 1999. The FNLMA brought into effect the terms and conditions agreed to in the Framework Agreement. It is the Framework Agreement that is actively being implemented by First Nations and Canada. ${ }^{32}$

This statement from the Lands Advisory Board, an institution established under the Framework Agreement and comprising representatives of several First Nations, makes plain how First Nations understand the Framework Agreement and the First Nations Land Management Act. As First Nations see it, the Framework Agreement, which is not federal legislation or policy, or an amendment to the Canadian constitution, represents a foundational agreement and source of law outside the traditional hierarchy of legal norms in the Canadian legal system, giving rise to obligations on the part of the Canadian government. So while it might be observed that the First Nations Land Management Act is a federal statute, as it is, and so stands in a familiar place in the hierarchy of legal norms in the Canadian legal system, the First Nations Land Management Act must also be seen as deriving its ultimate validity and authority from recognition by both the Canadian government and First Nations.

30 See a news release here: https://labrc.com/framework-agreement/, and the full text of the agreement here: https://labrc.com/wp-content/uploads/2016/08/FA-current-to-2013.pdf.

31 See https://labrc.com/framework-agreement/. At the beginning of 2019, 153 First Nations already had their own land codes or were actively developing them. See: www.aadncaandc.gc.ca/eng/1327090675492/1327090738973.

32 See https://labrc.com/framework-agreement/. 
What makes the Framework Agreement, together with the First Nations Land Management Act and the many First Nations land codes now in operation, an example of entangled legalities, and why is it important to understand the social situation in this way? It might be tempting to suppose that First Nations gaining greater control over management of their lands, which also includes the authority to create a range of criminal offences, ${ }^{33}$ authority which has historically been held in Canada by the federal government alone, represents a step towards independence of the sovereign state kind. If this were true, then we would not have an instance of entangled legalities but perhaps some form of secession then treaty under international law. However, under arrangements such as the Framework Agreement, fragmentation into several sovereign states within Canada is not contemplated. Rather, what is sought are forms of self-government which depend on mutual recognition and thick intermingling of norms and institutions from diverse sources of ultimate authority. A recent case provides a good illustration.

The K'omoks First Nation in British Columbia created their own land code in 2016 in accordance with the Framework Agreement and the First Nations Land Management Act. Section 31.1 of their land code reads: 'Any person who resides on, enters or remains on KFN [K'omoks First Nation] lands other than in accordance with a residence or access right under this Land Code or under a Law is guilty of an offence. ${ }^{34}$ Two nonK'omoks First Nation renters, Thordarson and Sorbie, had failed to pay their rent for several months on a property on K'omoks First Nation lands, and after having been given formal notice to vacate by the K'omoks First Nation, did not leave the premises. They were then considered trespassers by the K'omoks First Nation and guilty of an offence under the Land Code. As the Provincial Court of British Columbia recounts, the K'omoks First Nation requested assistance from the Provincial Prosecution Service and Federal Crown, a provincial institution and federal institution respectively, to help in prosecuting and enforcing the laws of the K'omoks First Nation Land Code, since the Land Code, in accordance with the Framework Agreement, makes reference to the Canadian Criminal Code, a federal statute, as establishing the process for prosecuting the range of criminal offences created in the

33 Section 22 of the First Nations Land Management Act, https://laws-lois.justice.gc.ca/eng/ acts/f-11.8/page-4.html\#docCont.

${ }^{34}$ K'omoks First Nation v. Thordarson and Sorbie [2018] BCPC 114, www.canlii.org/en/bc/ bcpc/doc/2018/2018bcpc114/2018bcpc114.html. 
K'omoks First Nation Land Code. However, 'both the Provincial Prosecution Service and Crown Federal have declined to assist K'omoks. ${ }^{35}$ The court writes:

This leaves the K'omoks First Nations in a situation where their case must be pursued under 22[3] [a] [of the First Nations Land Management Act]. The Band has a law on the books that may give relief from trespass, by way of a court order, but no ability to enforce the law without the cooperation of authorities outside the Band, unless it assumes the burden of prosecution.

K'omoks First Nations, therefore, has applied to this Court pursuant to s.508 of the Criminal Code for what has been deemed as a private prosecution or prosecution by the Band. That section of the Criminal Code provides a justice who receives information laid under s.505 shall hear and consider ex parte the allegations of the informant and the evidence of witnesses where he considers it desirable to do so. ${ }^{36}$

The idea of a 'private prosecution' of a criminal offence is a novel development in Canada, where criminal offences have always been considered as offences against the state so prosecutable only by the state. Private prosecution, however, is made possible by the nature and provisions of the Framework Agreement, the First Nations Land Management Act and particular First Nations land codes. ${ }^{37}$ The court concluded that the K'omoks First Nation was entitled to a remedy, and in this case to an order to remove Thordarson and Sorbie from the property on K'omoks First Nation land.

However, we need not take the characterization of 'private prosecution' at face value, as appearances might be deceiving, and there might be an alternative understanding available. What might look like private prosecution from one perspective could also be viewed as an assumption of public prosecution by a hitherto unrecognized institution. On this understanding the possibility of prosecution by the K'omoks First Nation was not a delegated power, expressly or implicitly provided by the federal government; the K'omoks First Nation did not, in this sense, pull on some chain of validity to initiate a criminal proceeding, but instead

35 K'omoks First Nation v. Thordarson and Sorbie, para. 15.

36 Ibid., paras 16-17.

37 For news coverage of the case, see B. Lindsay, "They Did It "Their Own Damn Selves": First Nation Wins Unusual Bid to Evict Bad Tenants', CBC News (8 October 2018), www .cbc.ca/news/canada/british-columbia/they-did-it-their-own-damn-selves-first-nationwins-unusual-bid-to-evict-bad-tenants-1.4852788. 
assumed and so created the power itself. If we keep in mind as well that criminal offences are typically considered to be the most serious forms of voluntary wrongdoing, which therefore concern not just individual victims but political communities in their entirety, then assumption of the power to prosecute can easily be understood as assumption of a public power to address issues which are not merely of a private nature. Recognition by state courts of such a power might then be much more than simply toleration of a private exercise of power by federal and provincial courts; it might be part of the mutual recognition by state and Indigenous authorities to share in the creation, application and enforcement of criminal law, which was once within the sole purview of the federal government but no longer.

The details of the K'omoks case show, we suggest, that it is implausible to see First Nations law and state law (provincial and federal) as representing distinct legal systems, operating independently at the level of both norms and institutions. The entanglement is unmistakable. The ultimate source of law and authority of First Nations land codes such as the K'omoks First Nation Land Code is shared between First Nations and the federal government by virtue of the Framework Agreement. And at the level of application and enforcement of law, norms sourced in First Nations law as well as federal law coexist and complement each other, and institutions from both the K'omoks First Nation and state government (e.g. provincial courts) are envisioned in a relationship of coordination and assistance. Thordarson and Sorbie might become a precedent-setting case, and likely one which establishes some of the relations of entanglement required for First Nations law and state law, as well as their respective institutions, to coexist and operate within Canada.

Still, one might object, why could we not understand the relation between the state and First Nations, in instances such as those presented in Thordarson and Sorbie, as distinct but interacting legal systems, much like some claim we see in the European Union where there are longstanding rival supremacy claims made between member state courts and the Court of Justice of the European Union on behalf of their respective legal orders? ${ }^{38}$ To see why, we must remember from earlier discussion that to be a legal system requires a distinctive claim to supremacy over all other legal and normative orders in the same social space, as the ultimate

38 See, e.g., N. MacCormick, Questioning Sovereignty: Law, State, and Nation in the European Commonwealth (Oxford University Press, 1999), chapter 7. 
foundation for all other applicable law, and this is precisely what is missing in the interaction between state and First Nation institutions regarding First Nation land codes. The foundation of such land codes is the Framework Agreement, a government-to-government framework of mutual understanding and recognition between the federal government and First Nation governments. In broader terms, as one of us elaborates elsewhere, ${ }^{39}$ legal systems are social constructions, constructed out of the beliefs, intentions, self-understandings and practices of relevant actors. Supremacy claims are part of the beliefs, intentions, self-understandings and practices of relevant actors for the creation and existence of legal systems, so where these are absent, legal systems are absent as well. The framework agreements, letters of understanding and reconciliation protocols we find in Canada are evidence that, however incrementally, the relevant beliefs, intentions, self-understandings and shared practices of state institutions and First Nation institutions are moving away from supremacy-claiming systematicity towards something else. Simply put, we might be witnessing the social reconstruction of the character of legal relations between the state and First Nations.

To bring the argument of this section full circle, even while further coordination is required to manage the entanglement, for First Nations law and state law to coexist, all that is required is mutual recognition of each other's legal orders. Claims of one order to supremacy over the other are neither necessary nor inevitable as a matter of social fact regarding the existence of law in the durable alignment and intimate relationship between law and society most familiar from the life of the sovereign state. And as we have seen, claims of supremacy, and in particular claims of supremacy made by state institutions over First Nations institutions, would only act as political obstacles to shared goals of reconciliation and partnership.

\subsection{A Conceptual Alternative to Legal System}

We have sought in this chapter to demonstrate that entangled legality exists, and that in at least the case of Canada-First Nations relations, it is viewed as desirable. Along the way we have undermined the applicability of the concept of legal system and opened the way to asking whether there is an alternative to the concept of legal system (and primarily its

39 See M. Giudice, Social Construction of Law: Potential and Limits (Edward Elgar, 2020). 
state-based form) for thinking about law in general, and more particularly the relations between legal orders. ${ }^{40}$ In previous work we have developed what we call an 'inter-institutional view of legality' amplifying themes found in Neil MacCormick's work on institutional normative order. The inter-institutional view is particularly useful for the explanation of relations between Canadian state institutions and First Nations legal institutions. The primary descriptive-explanatory benefit of our view lies in its showing how relations of mutual reference can arise between institutions within and across legal orders, operating in ways that need not be viewed as carrying implicit or explicit supremacy competitions as part of their purpose or function. Relations of mutual reference, whether codified in law or formal agreements, or simply found as a matter of social practice, may of course take the form and character of hierarchical relations of supremacy and comprehensiveness; but it is also possible for them to take the form and character of horizontal relations of partnership or shared governance, as we have seen in the case of Canada-First Nations relations. The actual form and character of relations of mutual reference, in other words, is variable, and contingent upon the particular ways in which social groups intend, practice and understand - that is, socially construct - their relations to each other.

The inter-institutional view is designed as a morally neutral descriptive-explanatory view of law, and as such, its possibility and success as a conceptual view of law stands or falls on its success in explaining in general terms (i.e. across as wide a range of contexts as possible) the social fact existence of law (including the existence of legal order between legal orders) wherever and whenever it exists. That said, if such a view is successful on descriptive-explanatory grounds, its adoption in practice may identify political options or possibilities of a morally desirable nature which might otherwise remain hidden from view under prevailing conceptual understandings, such as the understanding of law which ties it squarely to the idea of a state-based legal system. As we have seen in the context of Canada, where there is a politically desired goal of reconciliation between settler and Indigenous peoples, the interinstitutional view seems superior to the state system-centred view in making visible and characterizing a form of non-dominating, non-hierarchical relationship between legal orders. This reconceptualizing will not of course solve all legal, political, moral and economic problems, but it

40 See again, Culver and Giudice, Legality's Borders and Culver and Giudice, The Unsteady State. 
has the potential to address one particular challenge of reconciliation identified by Borrows, Turner and many others: the challenge of reconceiving the status of Indigenous peoples and their legal orders as something other than subordinate to the comprehensive and supreme Canadian legal system. ${ }^{41}$ The inter-institutional view of law may be a particularly useful precursor or accompaniment to politically viable reconciliation between Canada and First Nations.

Relations of mutual reference between institutions are also a particularly helpful tool for detecting the emergence of new legal orders, especially in contexts where there is a plurality of entangled sources of law. In the Canadian context, we might be witnessing a shift away from recognition of a unitary constitution and towards a plurality of constitutional sources. ${ }^{42}$ Since Confederation in 1867, the Constitution Act, 1867, then the Constitution Act, 1982, have served as the unitary Constitution of Canada. Yet if the socially accepted relations of mutual reference expand to include various foundational framework agreements, letters of understanding and the Royal Proclamation of 1763, these ultimate sources of rights and obligations might reasonably be viewed as constitutional moments, and so new (or revived) constitutional sources of law and authority. Unitary constitutions might be the ideal in some circumstances, but perhaps not so in others. Relations of mutual reference, which might follow existing, established law or might not, can be seen to have a kind of reconstitutional power if they occur at a basic, foundational level. Such reconstitutional power might not only be possible but highly desirable in some contexts.

Clearly, much remains to be done to specify how the inter-institutional view works as an alternative to system- or supremacy-centred views in particular contexts, including state-First Nations relations in Canada. This is not our aim here, as we aimed to demonstrate only the existence

${ }^{41}$ We also hope we are not read as supposing that such reconceptualization will be easy or straightforward. Like other social constructions, such as those of race, gender and disability, altering the social construction of law in Canada, beyond the handful of examples identified in this chapter, is likely to be slow and difficult, if it is accomplished at all. In general, the inter-institutional view is not a dominant, prevailing view. It is a mostly revisionary view.

${ }^{42}$ For sophisticated accounts of the nature and value of constitutional pluralism in a variety of contexts, see MacCormick, Questioning Sovereignty; N. Walker, 'The Idea of Constitutional Pluralism' (2002) 65 Modern Law Review 317-59; and N. Krisch, Beyond Constitutionalism: The Pluralist Structure of Postnational Law (Oxford University Press, 2010). 
of entanglement and its desirability in some circumstances, and in that context articulate a broader lesson regarding the contingency of the system- or supremacy-centred view and the consequent importance of exploring alternative explanations such as that offered by our interinstitutional view. We plan to continue this line of argument in future work. What does remain to be done here is to return to the organizing theme of legal entanglement.

A system-centred concept of law is one way of characterizing relations between multiple legal orders, so setting the basic terms of entanglement as ones of hierarchy, supremacy and delegation. As we have demonstrated, however, the system-centred concept represents one choice of explanation among others. In particular contexts, such as that of Canada, the choice of a system-centred concept may pose an obstacle to both the explanation of changes occurring in an evolving constitution and its relation to adjacent legal orders, and a further obstacle to an imaginative exploration of ways to achieve particular political objectives such as recognition and reconciliation between state institutions and Indigenous peoples. Exploration and development of basic terms of entanglement of mutual reference, partnership and non-hierarchical shared authority is therefore important not only as a tool for successful descriptive-explanation of the range of possible social facts comprising law, but also for surfacing conceptual choices which might assist in achieving morally desirable political objectives. We followed in detail one instance of legal entanglement in the example of application and enforcement of a First Nation land code, finding in this example the elements of a new, positively entangled First Nations-state relation showing the possibility of durable coexistence in an era of 'nation-tonation' or 'government-to-government' partnerships. Throughout our exploration of legal system, entangled legality and evolving state-First Nations relations, we have shown that there is choice in how to present, understand and reconceive foundational state-First Nations relations. This is a choice about the basic terms of legal entanglement, the basic terms about how relations among legal orders of different communities and cultures are to be characterized and practised, ahead of and during the task of working out the particular ways in which norms and institutions will interact and mutually refer to each other. 